\title{
Built-up Boundaries Outweigh Paper Boundaries
}

W

HATEVER conflict exists in law books, people must act upon existing boundary lines produced by houses on both sides and believed by the adjoining owners and the world to be boundaries. Repetition of litigation thereon carried to the highest courts (twelve California cases in the last five years) emphasizes that they are acted upon in practice. ${ }^{1}$ An article in this Review for March last ${ }^{2}$ presents the view that paper boundaries (in deeds and the like) nevertheless control in most cases, and "built-up" boundaries control only by exception; the paper preponderating against the fact. While there is conflict in the decisions, it is the object here to offer reasons for thinking that the law and the weight of California authority are for the preponderance of the line-in-fact, the built-up boundary, and that superiority of the paper line, when differing therefrom, is the exception. ${ }^{3}$

\section{By Contract.}

r. The obstacle in the way of the line-in-fact as against the paper line is the Statute of Frauds. "An estate in real property can be transferred only by operation of law, or by an instrument in writing." The statute is imperative, absolute, peremptory and comprehensive. To nevertheless introduce the subject of express parol agreements, we may consider a case of actual fraud. My neighbor, purposely to mislead me, tells me to build my house to such and such a line, and agrees to abide thereby. . When I have the house up he demands a big sum of money for two feet

1 Since 1910 there have been in California twelve cases taken up, seven in the Supreme Court and five in the District Courts of Appeal. There were others that finally went off on other points.

24 California Law Review, 179.

${ }^{3}$ A previous expression in this Review also takes a different view than the March article. 1 California Law Review, 370.

Settlement of overlapped boundaries by adverse possession is not included in this paper. The insufficiency of it to be full relief is due to its numerous conditions with which ordinary cases cannot comply; especially the payment of taxes.

${ }^{4}$ Cal. Civ. Code, $\S 1091$. See also Cal. Civ. Code, $\S \S 1624,1741$; Cal. Code Civ. Proc. \$\$ 1971-1973. 
of his land that I have encroached upon, and, on my refusal, sues to eject me. At the trial he walks backward and forward in the court and tells me "look at the statute." It says that I have no case.

That is, if such agreement is one of transfer of title to the overlap. Therefore, to meet the situation it is construed not such, in the usual case. The usual case of an express agreement is where the parties believed beforehand that the boundary's position was in doubt; they will not otherwise be found consciously taking up the subject; without that belief there is rarely anything to cause them to discuss it. An express boundary contract being usually, therefore, the settlement of a believed uncertainty, it is construed to be rather a definition, furnishing conclusive evidence between them as to where the line really is, than a transfer to one of what he did not before own. It is held not to be within the Statute of Frauds because, as so construed, it does not transfer anything.s

To be so construed, it must therefore be based upon a believed uncertainty as to the true line. ${ }^{6}$ And as it must have some consideration to make it a binding contract, the settlement of the uncertainty (clearing away the doubt from both parties) is at the same time mutual consideration. ${ }^{7}$ The removal of a doubt is always consideration in the law of contracts, if so intended. Examples upholding such express contracts settling an uncertain boundary line are given in the note, and as their validity is $a$ settled principle without conflict (if the agreement was distinctly proved and the minds of the parties fully inet) ${ }^{8}$ we cite these examples without more. ${ }^{9}$

5 Price v. DeReyes (1911), 161 Cal. 489, 119 Pac. 893; Young v. Blakeman (1908), 153 Cal. 482, 95 Pac. 888; I,ewis v. Ogram (1906), 149 Cal. 509, 87 Pac. 60, 117 Am. St. Rep. 151, 10 L. R. A. (N. S.) 610 . Compare the operation sometimes allowed to re-delivery or cancellation of title deeds, effective notwithstanding the Statute of Frauds. Browne on the 'Statute of Frauds, § 61 .

L Lewis v. Ogram (1906), 149 Cal. 510, 87 Pac. 60, 117 Am. St. Rep. 151, 10 L. R. A. (N. S.) 610. Accord, Thaxter v. Inglis (1898), 121 Cal. 594, 54 Pac. 86; Nathan v. Dierssen (1901), 134 Cal. 284, 66 Pac. 485; Mann y. Mann (1907), 152 Cal. 23, 27, 91 Pac. 994; Clapp v. Churchill (1913), 164 Cal. 742, 130 Pac. 1061; Schwab v. Donovan (1913), 165 Cal. 360, 364, 132 Pac. 447. "Uncertainty" does not require the line to be "unascertainable." Price v. DeReyes (1911), 161 Cal. 489, 119 Pac. .893; Loustalot v. McKeel (1910), 157 Cal. 634, 643, 108 Pac. 707.

7 Supra, n. 6.

8 Clarke v. Huber (1864), 25 Ca1. 597; Helm v. Wilson (1891), 89 Cal. 596, 26 Pac. 1103.

O Dierssen v. Nelson (1903), 138 Cal. 398, 71 Pac. 456; Woodward 
2. If there is no believed uncertainty, the parties may be in one of two conditions; either they may be in the negative condition where it did not enter their thoughts, both believing, in ignorance or mistake, that the line is all right as it is; or they may be in the condition of knowing perfectly where it is or ought to be. In the former of these two cases they will not be found contracting since, by hypothesis, the matter is not thought of. To inquire whether an express agreement would be valid in such situation is like asking whether an irresistible force can budge an immovable body; they cannot exist at the same time and place, being self-contradictory; if the parties have it not in mind they are not negotiating. Such negative cases of passive ignorance as distinguished from active doubt cannot enter the region of express contracts, and must be left aside. In fact, it is the main point of this article to emphasize this. ${ }^{10}$ The other condition, of changing a known line, is the least important of any, since this will usually be done by cross-deeds voluntarily.

Occasionally the shifting of a known lime is sought by an express boundary contract as a convenient short cut in place of crossdeeds. This is now held invalid, ${ }^{11}$ although an early case seems to have upheld it. ${ }^{22}$ There are three reasons given: there is no settlement of an uncertainty to take it out of the Statute of Frauds, since intentional transfer of a known overlap cannot be construed as a mere definition of existing ownership, where it is well known by the parties not to be such; it would be invalid, even if written, as an attempt to convey without words of conveyance; without settlement of a doubt there is nothing to furnish consideration.

3. These are the main points controlling express boundary contracts. Some of the contract cases make note that long acquiescence followed. They do not, however, any of them lold it nec-

$\because$ Faris (1895), 109 Cal. 17, 41 Pac. 781; Cavanaugh v. Jackson (1891), $91 \mathrm{Cal}$. 582, 27 Pac. 931. "The parties entered into an express agreement fixing the dividing line;" Silvarer v. Hansen (1888), 77 Cal. 579, 583, 20 Pac. 136; Cooper v. Vierra (1881), $59 \mathrm{Cal}$. 282. The point is conceded in all the cases passim. Cf. Tuffree v. Polhemus (1895), 108 Cal. 670, 41 Pac. 806 (executed parol partition).

10 See par. 6, page 299 , infra.

11 Thaxter v. Inglis (1898), 121 Cal. 594, 54 Pac. 86; Lewis v. Ogram (1906), 149 Cal. 510, $87^{\prime}$ Pac. 60, 117 Am. St. Rep. 151, 10 I. R. A. (N. S.) 610; Mann v. Mann (1907), 152 Cal. 23, 91 Pac. 994; Clapp v. Churchill (1913), 164 Cal. 742, 130 Pac. 1061.

12 Moyle v. Connolly (1875), 50 Cal. 297. 
essary; it has on the contrary been held not to enter into express agreements. ${ }^{13}$ It is here mentioned only to suggest in advance the distinction between cases of contract and the separate class of cases to which this article is hereafter mainly addressed.

\section{By Estoppel.}

4. Leaving behind parol agreements founded upon a promise and consideration, as well as parol licenses upon a promise but no consideration, there is sometimes assurance not of a promissory kind. These cases are where a party has admitted the boundary at a certain place, but has done no more, nor promised his neighbor any land, nor even promised to abide by that location. It is the case where, knowing that his neighbor wants to build, the party (who, it afterwards turns out, is encroached upon) points (on the grounds or on a map or by verbal description) to a fence, for example, and says, "That is the line," but says nothing involving promise. When acted upon by building houses thereon, the adinission, which is always prima facie evidence against the man who made it, becomes conclusive evidence. Although there was nothing promissory connected with it, yet because of the "equitable fraud" in the consequences of a denial of his admission under such circumstances, in equity he will not be heard to deny it. It is a strict case of estoppel in the true sense. Equity stops him if he tries to give evidence contrary to what he had previously admitted and the other had acted upon. ${ }^{14}$

While the word estoppel is loosely used in cases of another

13 "Where the owners of contiguous lots by parol agreement mutually establish a dividing line, and thereafter use and occupy their tracts according to it for any period of time, such agreement is not hin the Statute of Frauds." Cavanaugh v. Jackson (1891), 91 Cal. 582, 27 Pac. 931. In another case: "The force of the instruction was somewhat impaired by requiring the acquiescence of the parties for the term of five years in the line thus established. Such acquiescence would probably be requisite in order to give validity to a line not located according to the calls of the deed, but when the parties, by running and marking the line upon the land, identify a call which, from the language of the deed, is left in uncertainty, acquiescence will add nothing to the conclusiveness of the location of the line." Hastings v. Stark (1868), 36 Cal. 126, 127. See Tiffany on Real Property, § 259.

14 This principle is, for example, stated as follows: "In addition to estoppels by deed there are two classes of admissions which fall under this head of conclusive presumptions of law; namely, solemn admissions, .... and unsolemn admissions, extra judicium, which have been acted upon, or have been made to influence the conduct of others, or to derive some advantage to the party, and which 
nature hereafter considered, there are numerous California cases of strict estoppel based upon an actual pointing out. For example: "They employed the county surveyor to run a line, and told Huber of that fact, to which he said, 'All right; survey the land.' $\mathrm{He}$ was present part of the time when the survey was being made; he talked about the line, and said 'He supposed they would be all right; he came and examined the stakes afterwards; he was where the stakes were put after the survey was done; he made no objection." The court said: "It is true that the language used by him when the line was being run was not extremely express and explicit, but, taken in connection with the facts that he built a fence on the line and ever afterwards acquiesced in such line, it was clearly sufficient to justify the finding of the court on the subject" The line was held irrevocable.15 In a more recent case "Bennett, as the original owner of both tracts, would presumably have knowledge of the location of the lines superior to that of the defendants. He pointed them out to Reyes, who desired at that time to know their position." When built upon, this lime was held irrevocable..18 Still more recently: "The lines thus admitted by Pomeroy extended to the corners and there intersected the projected end lines of the Villa homestead claim. Thus it would include the parcel now in dispute. Under these circumstances we think the estoppel is established."'17

And where there is such pointing out (there being no contract requiring a consideration) the parties are held entitled to

cannot afterwards be denied, without a breach of good faith. ... The latter class comprehends, not only all those declarations, but also that line of conduct by which the party has induced others. to act or has acquired any advantage to himself." 1 Greenleaf on Evidence, $\$ 27$. "If A claims that his boundary line runs to an oak tree, and B admitted this, B's extra judicial admission of the boundary's location is merely evidence for the truth of the other facts on which A rests his claim. But if $B$ has made his statement to $A$ under such circumstances that $A$ was justified in =ating on it and has since built up to the line he claimed, B's concession may by estoppel become the foundation for a new right for A, wholly irrespective of the validity of the grounds of his original claim." In Wigmore Evidence, $\$ 1056$. It is enacted in the Code of Civil Procedure of California: "Whenever a party has, by his own declaration, act, or omission, intentionally and deliberately led another to believe a particular thing true, and to act upon such belief, he cannot in any litigation arising out of such declaration, act, or omission be permitted to falsify it." Cal. Code Civ. Proc. § 1962, subd. 3. See Washburn on Rea1 Property, $\S 1895$.

15 Dierssen v. Nelson (1903), 138 Cal. 399, 71 Pac. 456.

16 Price v. De Reyes (1911), 161 Cal. 486, 119 Pac. 893.

17 Grant's Pass Land etc. Co. v. Brown (1914), $168 \mathrm{Cal} .462,143$ 
believe in the correctness of the location. ${ }^{18}$ This is the opposite from having to believe that there was uncertainty.

\section{By Operation of Law.}

5. As stated in the above quotations, the admission (which by estoppel becomes conclusive evidence against him) may be by conduct as well as by word of mouth. The serious question is what conduct is sufficient to constitute an admission upon the matter. The most frequent cases of overlapped buildings are within this conflict; cases where neither party had suspicion of a boundary question until it turned up after houses were built, and there was consequently at the time neither agreement on consideration, promise or license without consideration, nor even any admission unless the silence while seeing the other's house being built be such.

Is this silence sufficient? We may say confidently that it is not. If I see another man building in the middle of my land thinking it is his, I have the full period of the statute of limitations to eject him. If I did not know, I have the statutory period after I discovered. My silence raises no estoppel. ${ }^{13}$ A frequent illustration is in water cases, where standing by while seeing another divert a stream at much expense, thinking he has a right to do so, raises no estoppel. ${ }^{20}$ In the similar boundary cases the situation is in formal aspects the same; the party overlapped, not

Pac. 754. So likewise Columbet v. Pacheco (1874), 48 Cal. 397: "Defendants are estopped from controverting the correctness of the location." Hughes v. Wheeler (1888), 76 Cal. 231, 18 Pac. 386: "Such acts estop him from claiming." As in other cases of estoppel, the pointing out must be under positive circumstances. If pointed out as a guess only, stating at the same time that he did not know whether it was actually the line or not, there is no assurance held out, and can be no estoppel. Maye v. Yappen (1863), 23 Cal. 309, 10 Morr. Min. Rep. 101.

${ }_{18}$ Schwab v. Donovan (1913), 165 Cal. 360, 132 Pac. 447. See also Biggins v. Champlin (1881), 59 Cal. 116, where "Munday pointed out a line to the defendant as the correct line. Defendant thereupon built the part of the fence he was required to build, on the line so pointed out, Munday building the other portion," and the court held: "It makes no difference that the parties, in making the location, acted under a mistake as to the true line."

19 Boggs v. Merced Co. (1859), 14 Cal. 279, 10 Morr. Min. Rep. 334; Lux v. Haggin (1886), 69 Cal. 255, 4 Pac. 919, 10 Pac. 674. If he has taken possession for a public use, or if my action is in equity, my inaction may bar me of any relief but damages; but my silence does not estop me completely of relief even in the exceptional cases where I can get only damages.

20 Wiel, Water Rights, 3d ed., §593 et seq. 
knowing he had a right to object, has been simply silent until he discovered it. There is neither admission when the silent party had no knowledge, nor is there reliance by the second party upon such silence. When the second party, having also no reason to doubt the line's position, builds there, he does not look to the first party's silence as reassurance; he does not think of reassurance; he acts upon his own confidence as to where the line is. The cases refuse to uphold the new line by estoppel under such circumstances, and in refusing seem to correctly apply the estoppel doctrine.

6. But in practical aspects the boundary situation differs greatly in degree from the other cases. It is so vastly more likely to happen; indeed it is happening every day. Variation from paper descriptions is incessant from inaccuracy of early surveys, mediocre or poor work in recent surveys (a feature common to a large percentage of all work) changes of position of monuments, which changes are often unknown, variations due to different makes of surveying instruments, earthquakes (sometimes - it twisted numerous streets a foot or.more out of place in San Francisco) and all the other contingencies which prevent any work of man from being absolute. This liability to variation from the paper title is vastly more common in boundary lines than in other like matters. ${ }^{21}$ Also, the consequences

21 "Experience shows that such measurements, made at different times by different persons with different instruments, will usually vary somewhat. The position of the object or monument at which the course begins may also be changed and the change may but be known to the parties, or there may be no means of ascertaining its orginal position. If the position of the line always remained to be ascertained by measurement alone, the result would be that it would not be a fixed boundary, but would be subject to change with every new measurement. Such uncertainty and instability in the title to land would be intolerable." Mr. Justice Shaw in Young v. Blakeman (1908), $153 \mathrm{Cal}$. 481, 95 Pac. 888. Likewise, "No absolutely accurate survey ever was or ever will be made. In order to build cities and towns there must be some finality as to the location of blocks and streets. Under such an ordinance, if valid, there could be none. All lines would be forever subject to be revised and corrected, or changed by new surveys not really more accurate, but only for the time deemed so." Oreña v. City of Santa Barbara (1891), 91 Cal. 630, 28 Pac. 268. And again: "The inaccuracy of the early surveys in California, as well as in other states, is a matter of such common knowledge that the courts are warranted in taking judicial cognizance of the existence of such inaccuracy, as they frequently have done." Hellman $v$. City of Los Angeles (1899), $125 \mathrm{Cal}$. 387, $58 \mathrm{Pac}$. 10. And still again: "That they (government surveys) abound in mistakes is notorious, and is evidenced by the reported decisions of nearly every State save the original thirteen. Nor are the ordinary surveys quite infallible. Their 
of disturbing the built-up line usually are far more disproportionate to the innocent encroacher, if, for but a few inches of overlap, a large and costly building is put at the other's mercy, as it is if the overlap is denounced. The largest office building standing for years and the smallest residence would never be sure lest an inch or two or a foot or two might be shaved off one or all sides, or the house have to be moved or the owner. subjected to an extortionate demand for money. If the position usually remained to be ascertained from paper alone the result would usually not be a fixed line. If the line as built were subject to correction on new surveys, the confusion of lines and titles would cause consternation. Indeed, the mischiefs that must follow any depreciation of boundary lines as marked by the buildings themselves would be such as to make the visitation of the surveyor a great public calamity.

By nevertheless refusing to recognize any estoppel here we have not thereby cast out all grounds of relief. Still another ground of relief remains.

This remaining ground is by operation of law, which is expressly excepted out of the Statute of Frauds. ${ }^{22}$ The operation of law arises from a matter that is arbitrary until crystallized by repeated decision, namely, public policy. Because of late this has been an unruly steed liable to break all law harness, the first ride upon him may truly cause concern as to what is going to happen. But after repeated decisions already made bring us to a certain rule of law that has long been explained upon a public policy ground, the fact that they have their explanation in public good is hardly a reason for discarding them.

The public policy long invoked to explain these acquiescence cases that are neither contracts nor estoppels, is the elemental policy of repose. The growth of changed conditions that cannot be retraced; the loss of evidence by time; these and other obvious things make rules of repose of the utmost social importance. It would be contradicting a fundamental principle of human nature to give no effect to silence however long. We

successive surveys nearly always disagree. This, aside from frequent carelessness or incompetency, is inevitable, from the variations of the needle, and slight differences in measurement over uneven ground." Miller v. Mills County (1900), 111 Iowa, 654, 82 N. W. 1038.

22 Cal. Civ. Code, $\$ 1091$, Cal. Code Civ. Proc. \$ 1971. The exception is in section 3 of the original English Statute, 29 Chas. II. 
have on this ground statutes of limitations. We have for incorporeal hereditaments the non-statutory prescription. Upon corporeal land the public policy fixing built-up boundaries by lapse of time and changed conditions, effective by operation of law expressly excepted from the Statute of Frauds, is the application to land of the same public policy that gave rise to prescription which survived the Statute of Frauds for incorporeal hereditaments, statutes of limitations being unsatisfactory, for various reasons, to meet the situation. In a case frequently cited it is said: "The supposition of such an agreement, in cases of long acquiescence in an established line, is, as I apprehend, entirely superfluous ... . The rule seems to have been adopted as a rule of repose, with a view to quieting titles; and rests upon the same reason as our statute prohibiting the disturbance of an adverse possession which has continued for twenty years ... The plaintiff is precluded, upon principles of public policy, from setting up or insisting upon a line in opposition to one which has been steadily adhered to upon both sides for more than forty years. If necessary, in order to establish this line the law will presume a conveyance in accordance with it."2s As stated by Mr. Justice Shaw, "The object of the rule is to secure repose, to prevent strife and disputes concerning boundaries, and make titles permanent and stable."24

Like the lost grant in prescription which was originated by the common law courts out of the public policy of repose, an agreement is said to be presumed in the boundary cases. The presuinption, however, is not a question of evidence nor as a fact, but as the convenient form of stating the doctrine of repose upon public policy, by operation of law. The presumed grant in prescription is well known not to be a matter of evidence; no evidence will be heard to show whether there was a grant or not. These are not cases of contract at all. The agreement is a pure fiction; the most familiar in the law. The implied contract spoken of in the boundary cases to which we

23Baldwin v. Brown (1857), 16 N. Y. 359: "It is the settled rule in this State, resting upon public policy, that a practical location of boundaries which has been acquiesced in for a long series of years will not be disturbed." Katz v. Kaiser (1897), 154 N. Y. 294, 298, 48 N. E. 532.

24 Young v. Blakeman (1908), 153 Cal. 482, 95 Pac. 888. The doctrine is referred to "the policy of the law" in Cavanaugh v. Jackson (1891), 91 Cal. 583, 27 Pac. 931, and Loustalot v. McKeel (1910), 157 Cal. 643, 108 Pac. 707. 
shall now proceed is not a matter of proving a contract either; $;^{25}$ it is but a mode of saying that acquiescence in the built-up line, followed by change of conditions, produces repose by operation of law, from the policy of the law, as though there were an agreement although there is none. ${ }^{26}$

A similar operation of the doctrine of repose occurs, for example, in the law of watercourses. Artificial flows of water are found whose beginning is buried so deep in the past that all evidence is lost of the circumstances under which they arose, and it is held that parties creating them are presumed to have agreed that they shall not be stopped, and no actual agreenent is looked for, the reference to agreement being a mere form of words; a mere fiction like the lost grant in prescription. ${ }^{27}$ Fictitious promises, implied by law and not open to imquiry, exist also in other parts of the law. ${ }^{28}$

25 "It is said in other cases that after a long acquiescence in a division line, varying from the true line, the Court is authorized to presume a grant of the excess, (See Adams v. Rockwell (1836), 16 Wend. 285 ), but it is unnecessary to presume anything more than an agreement upon the division line." Sneed v. Osborn (1864), 25 Cal. 619, 630.

26 Sneed v. Osborn (1864), 25 Cal. 619: "The acts of the parties might not amount to an agreement between them and it is unnecessary to consider them in that view." Brown v. Leete (1880), 2 Fed. 440, 6 Sawy. 332: "No express agreement need be shown." Again: "Indeed, it seems to be the settled doctrine in New York that the practical location and long acquiescence in a boundary line are conclusive, not on the ground that they are evidence of a parol agreement fixing it, but because they are proof that the location is correct, of so strong a character as to preclude evidence to the contrary. Reed v. Farr (1866), 35 N. Y. 113; Baldwin v. Brown (1857), 16 N. Y. 359, 364. In the last case it was said "acquiescence, in such cases, affords ground not merely from inference of fact to go to the jury as evidence of an original parol agreement, but for a direct legal inference as to the true boundary line," etc. Miller v. Mills County (1900), 111 Iowa, 654, 82 N. W. 1038. And again: "Acquiescence does not presuppose an agreement to a line. Nor is it essential that the jury find such agreement, express or implied, as a condition precedent to the application of the doctrine, as it was told. On the contrary, an agreement to a boundary is to be inferred from long acquiescence.... After the lapse of ten years, in the interest of peace and quiet they are not permitted to gainsay the agreement thus inferred." 1 C. J. 906 , note 19 c.

27 Whitmores v. Stanford (1900), 1 Ch. 427; Bailey v. Clark (1902), 1 Ch. 649; City of Reading y. Althouse (1880), 93 Pa. St. 400; Ford v. Whitlock (1855), 27 Vt. 265; Hollett v. Davis (1909), 54 Wash. 326, 103 Pac. 423, 426; Pacific Livestock Co. v. Davis (1911), 60 Ore. 258, 119 Pac. 147; Falcon v. Boyer (1913), 157 Iowa, 745, 142 N. W. 427; Cloyes v. Middlebury. E. Co. (1907), 80 Vt. 109, 11 L. R. A. (N. S.) 693, 66 At1. 1039; Woodbury v. Short (1845), 17 Vt. 387, 44 Am. Dec. 344, and other cases cited in Wiel, Water Rights, 3d ed., $\$ 60$.

28 "The history of the Action of Assumpsit has been described by a writer to whom lawyers and historians alike owe much, the late Professor Ames of Harvard University, in language which shows how 
7. The California rulings giving recognition to the operation of the doctrine of repose (operating not by contract or estoppel but upon public policy by operation of law and thereby expressly excepted out of the Statute of Frauds) are so numerous, including most of the recent cases, that we submit that they represent the rule in California.

The leading case is Sneed v. Osborn, ${ }^{29}$ at the same time the pioneer case in this jurisdiction. The statement of law, for which it has been cited down to the latest cases and always as in good standing is this $:^{30}$

"The acts of the parties might not amount to an agreement between them, to locate the tract as then surveyed, and it is unnecessary to consider them in that view; but do they not show an acquiescence by the parties in those lines as the division lines between the two tracts of land? If they do show such acquiescence it will make no difference in the result that they acted in ignorance or under a mistake as to the true northern line of the southwest quarter of the Harrison tract. The authorities are abundant to the point that when owners of adjoining lands have acquiesced for a considerable time in the location of a division line between their lands, although it may not be the true line according to the calls of their deeds, they are thereafter precluded from saying it is not the true line." 31

The ruling is explicit that acquiescence with lapse of time is in itself a sufficient operative principle. "Agreement" is expressly repudiated, being but a presumed fiction, a mere form of words, not permitted to be controverted.

To quote the like subsequent rulings would result in pretty nearly a digest of the California cases. We can but cite them, quoting a word or two fairly typical of the context and of the facts upon which the cases were rested. All count upon acqui-

easily the fiction of a promise grew into part of the law." Lord Haldane, Chancellor, in Sinclair v. Brougham, 30 T. L. R. 315.

29 Sneed v. Osborn (1864), $25 \mathrm{Cal}$. 619.

30 It has been cited with approval in twenty-three California cases, and six other cases outside of California; number shown by Rose's citations and the other California citators.

${ }^{31}$ Sneed v. Osborn (1864), 25 Cal. 619, 626. The same case came before the court a second time. Sneed v. Woodward (1866), 30 Cal. 430,434 , and was reaffrmed, the court saying: "The state of the defendant's evidence was such that it might be inferred by the jury that, notwithstanding an erroneous location according to the Ide survey, Sneed and McNeil, under whom Sneed claimed the ten acre tract, had asquiesced in the erroneous location for a period so long as to estop them from questioning it." 
escence as the determining element. While some use additional forms of words, such as "implied agreement," "estoppel" and the like, these are, as already shown, only forms of words to emphasize that repose is established. ${ }^{32}$

Following Sneed v. Osborn, the court said: "Their acts in locating the lines, in such a case are evidence that the lines established by them are correct." "33 "Assuming, as we properly may, that at least from $185 \mathrm{I}$ to 1866 the location of the fence, as a dividing line between the lots, was acquiesced in by the coterminous owners, the defendants are estopped from controverting the correctness of the location." ${ }^{34}$ "Besides, where owners of adjacent parcels of land have occupied, adversely to each other for more than five years, their respective tracts by a division line, which each has recognized and acquiesced in as the true line, during all of that time, either is estopped from afterwards questioning it as the true line." 35 "And where it is proved that a line has been agreed upon either expressly or by long acquiescence, as the dividing line between two tracts of land, courts will not disturb the line." 36 "It may be settled between them by a location made by both, or made by one and acquiesced in by the other for so long a time as to be evidence of an agreement as to the line." ${ }^{\prime 37}$ In the following case, the party constructed a fence, occupied, cultivated, and improved for a period of sixteen or eighteen years, with the knowledge of the plaintiffs, who made no objection. "There was a silent assent or submission, with apparent consent, as distinguished from avowed consent and from opposition or discontent," and "acquiescence

32 "The courts often say that it would be inequitable for the parties, after such long acquiescence in a partition line, to set up another .... that they are estopped from making such proof; but it is not meant thereby that either party holds by an equitable title, or that title accrued to him by estoppel." Sneed v. Osborn (1864), 25 Cal. 630. For example, in Schwab v. Donovan (1913), 165 Cal. 360, 364, 132 Pac. 447, an agreement to pay part of the cost of the fence was held to imply an agreement to keep the line there always; the court, for a reason hereafter noted, straining to find an agreement when its real ruling was that none was needed. The court lays stress upon the acquiescence which followed and which was the determinative feature without any agreement.

33 Hastings v. Stark (1868), 36 Cal. 122, 126.

34 Columbet v. Pacheco (1874), 48 Cal. 395, 397.

35 Johnson v. Brown (1883), 63 Cal. 391, 393.

36 Truett v. Adams (1884), 66 Cal. 218, 223, 5 Pac. 96.

18 Pac. 386.

${ }^{37}$ Instruction affirmed. Hughes v. Wheeler (1888), $76 \mathrm{Cal} .231$, 
in the location of a fence as a dividing line between two lots for a period of sixteen years estopped the defendants from controverting the correctness of the location." 38 In another, "Without any agreement more than is implied from their acts."39

What may be called the "recent" cases, begin with the opinion of Mr. Justice Shaw in Young v. Blakeman. ${ }^{40}$ The court ruled: "The evidence of the fact (agreed location), though entirely circumstantial, is reasonably satisfactory." The next is Dundas v. Lankershim District ${ }^{41}$ in which the conclusive facts are stated by the court to be that the point of begimning was marked on the ground; lines were then fixed on the ground by reference thereto; the parties occupied up to these lines; all parties acquiesced in this location and occupation. The court said this "must be accepted as the point of beginning actually described in the deeds, regardless of the accuracy of the actual location, as it may appear by subsequent measurements." The next is Loustalot v. McKeel42 in which the court said: "Still the rule of law is that where parties in good faith establish a boundary line which may not be in fact the true line according to the calls of their deeds, and in which they acquiesce and according to which they occupy their respective lands for a period of time equal to that prescribed by the statute of limitations, both parties and their successors in interest are conclusively estopped from questioning it as the true line." The next is Price v. De Reyes, ${ }^{43}$ in which plaintiff and his predecessor lived opposite for several years and were fully aware of the improvements and claim but made no objection, and it was said of judgment for the plaintiff entered below: "The decision of the court below, upon the facts appearing in evidence, was contrary to a long line of decisions of the Supreme Court of this state establishing the rule applying to the location of boundary lines between coterminous landowners." At this point comes in Clapp v. Churchill, ${ }^{4 *}$ hereafter further noted, discrediting the doctrine.

38 Burris v. Fitch (1888), 76 Cal. 395, 398, 18 Pac. 864.

39 Helm v. Wilson (1888), $76 \mathrm{Cal} .476,486,18 \mathrm{Pac} .604$.

40 Young v. Blakeman (1908), $153 \mathrm{Cal}$. 477, 481, 95 Pac. 888.

4I Dundas v. I,ankershim School District (1909), $155 \mathrm{Cal} .692,102$ Pac. 925.

42 Loustalot v. McKeel (1910), 157 Ca1. 634, 108 Pac. 707.

43 Price v. De Reyes (1911), 161 Cal. 484, 119 Pac. 893.

44 Clapp v. Churchill (1913), 164 Cal. 741, 130 Pac. 1061; Fitzimons v. Atherton (1912), $162 \mathrm{Cal} .630,124 \mathrm{Pac}$. 250 , is referred to in paragraph 8 , page 306 , infra. 
But the doctrine is immediately re-asserted in Schwab v. Donovan, ${ }^{45}$ quoting Young v. Blakeman and saying that "acquiescence ... goes far to confirm the view that the transaction of I888 was intended to operate as an agreement fixing the boundary," and in Grant's Pass Company v. Brown ${ }^{48}$ quicting Young v. Blakeman and citing Sneed v. Osborn. The last case at this writing was in the District Court of Appeal for the Third District, giving an emphatic ruling based solely upon the necessity of repose from lapse of time. ${ }^{47}$ The doctrine is often repeated in other states. ${ }^{18}$

A common instance is where the line was set by a common grantor of both parties and acquiesced in by them after purchase, although they had no part in setting it."

8. Acquiescence is, of course, essential to bring the doctrine of repose into operation. The public policy of not reopening

\footnotetext{
45 Schwab v. Donovan (1913), 165 Cal. 360, 132 Pac. 447, noted supra, n. 34.

${ }_{46}$ Grant's Pass Land \& Water Co. v. Brown (1914), 168 Cal. 456, 143 Pac. 754

47 Perich v. Maurer (1916), 22 Cal. App. Dec. 42, 155 Pac. 471, saying: "Its existence for so many years, the recognition accorded it as the true boundary, the acquiescence of the respective owners in the location and the improvements made accordingly were rightfully regarded as important if not decisive considerations in the determination of a line otherwise obscure and uncertain. It is true that no one testified directly that the boundary was actually located on the ground or that there was uncertainty in reference to it, but such may be fairly inferred from the various facts disclosed, and we may invoke the principle announced in Schwab v. Donovan (1913), 165 Cal. 360, 132 Pac. 447, and cases therein cited. This must be especially true since there is no clear and satisfactory showing here that the legal title is different from what is indicated by the fence." The other rulings in the District Courts of Appeal have, since Clapp v. Churchill, been affected by the attempts to follow that case, as hereafter mentioned.

48 For example, acquiescence is "conclusive evidence of such an agreement," Miller v. Mills County (1900), 111 Iowa, 654, 82 N. W. 1038, further saying: "The rule will be found perspicuously stated in Sneed v. Osborn." Likewise Keller v. Harrison (1908), 139 Iowa, 383, $116 \mathrm{~N}$. W. 327, saying: "Defendant is completely barred by this practical location and acquiescence, as he would have been had he ratified it by his own deed." Diehl v. Zanger (1878), 39 Mich. 601, Judge Cooley, concurring and saying: "a boundary line long treated and acquiesced in as a true line ought not to be disturbed on new surveys." Dupont v. Starring (1880), 42 Mich: 492, 4 N. W. 190; Major's Heirs v. Rice (1874), 57 Mo. 384; McCormick y. Barnum (1833), 10 Wend. 104, 105; Baldwin v. Brown (1857), 16 N. Y. 359, 364; Reed v. Farr (1866), 35 N. Y. 113; Crandall v. Mary (1913), 67 Ore. 18, 135 Pac. 188; Parker v. Wolf (1914), 69 Ore. 446, 138 Pac. 463; Farr Development Co. v. Thomas (1912), 41 Utah, 1, 122 Pac. 906 (citing other Utah cases); 5 Cyc. 938.

49 Price v. De Reyes (1911), 161 Cal. 484, 119 Pac. 893; Flynn v.
} 
ancient matters long thought closed does not enter where it was not closed because either party kept it open. Acquiescence in the line as a boundary is, by definition, essential.

The chief illustration of the absence of acquiescence is where the line is marked conditionally only. It is, in that case, an approximation only for the time being, with an intentional reservation that the paper line may be looked for and may govern when found. There is in that case no acquiescence in the line as a boundary. Thus where the parties "agreed to measure off with a tape-line, their respective lots, put up temporary fences, and that when the true lines should be ascertained each should have his land according to the true lines," the court held: "The rule laid down in Sneed v. Osborn has no application here, for there the parties were not running a mere temporary line, as was done in this case, but were establishing what they then understood to be the true line, and it cannot be said here, as was said there, that the parties have acquiesced, for any period, in the lines which were run as the true lines." "5o So also where "the fence was erected solely for convenience sake in renting said houses, and was not designed to be, nor was it considered as a boundary or division line." 51 A typical case is White v. Spreckels ${ }^{52}$ where a fence was permitted as a temporary accominodation only, not intending it to be an actual boundary, and no actual occupation up to the fence followed. ${ }^{53}$ So also where one of the parties was absent and did not know of the fence, 54 or where the asserted location of the line was never in fact completed, ${ }^{55}$ or where the line continued always to be in dispute. ${ }^{58}$

Glenney (1883), 51 Mich. 580, 17 N. W. 65; Sullivan v. Michael (1905), 39 Tex. Civ. App. 564, 87 S. W. 1061; Turner v. Creech (1910), 58 Wash. 439, 108 Pac. 1084. This is recognized in Clapp v. Churchill, infra.

50 Irvine v. Adler (1872), 44 Cal. 559, 562.

51 Sheils v. Haley (1882), 61 Cal. 157, 158.

62 White v. Spreckels (1888), 75 Cal. 610, 616, 17 Pac. 715.

53 So also in another case: "Tapper was called as a witness for the plaintiff, and denied that anything was said between him and the defendant about changing the lines of the 'fences if they should afterward ascertain that they were not correct; but the court below evidently believed the defendant, as it found in his favor on every point. Assuming the defendant's testimony to be true, it is clear".... etc. Quinn v. Windmiller (1885), $67 \mathrm{Cal}$. 463, 8 Pac. 14. See also Peters v. Gracia (1895), 110 Cal. 89, 42 Pac. 455; Honaker v. Heatly (1913), 21 Cal. App. 329, 131 Pac. 759; Janke v. McMahon (1913), 21 Cal. App. 781, 133 Pac. 21.

st Fitzimons v. Atherton (1912), 162 Cal. 630, 124 Pac. 250.

55 "Where such agreement extends to a part, only, of the line, it 
"Of course, the building of a fence does not always conclude the parties as to the boundary line; it may have been built for mere temporary purposes and with no intent to make it the permanent boundary."57 Without acquiescence the doctrine of acquiescence cannot operate.

Besides acquiescence, change of circumstances during the acquiescence is also obviously essential.

Where the acquiescence has been prolonged, loss of evidence by time is always a resulting change of circumstance sufficient to operate the doctrine of repose. "Where a suitor before proceeding permits such a lapse of time that the evidence has become obscured or lost, relief will be denied because of the difficulty of doing justice. While the rule requires for its support no element of estoppel, but is founded on public policy, the fact that the delay has tended to defeat defendant's power to prove his right is an additional reason for its application ... . The loss or obscuration of evidence will be presumed from a considerable lapse of time."'58 There seldom remains evidence that the monuments now found were planted at the time of the original survey, and that the survey was made with those monuments as a guide, and was itself mathematically correct. That the discrepancy existed when the house was built, instead of having crept in during later years, becomes pure assumption. Obscuration of monuments, changes of surroundings, death of parties and witnesses, departure of others from the locality,-these. and the like are inevitable. An instance of this is the opinion of Mr. Justice Burnett in the latest California case at this writing. ${ }^{59}$

cannot be extended by construction or implication, so as to embrace a part of the bounds which were not considered or included in the agreement and as to which there was no agreement." Grant's Pass Land etc. Co. v. Brown (1914), 168 Cal. 461, 143 Pac. 754.

56 "... no acquiescence in that line was shown, but, on the contrary, when appellant did enter upon the strip of ground and begin to make improvements thereon it was met by this suit by which it was called upon to establish its legal right to be there." Wheatley v. San Pedro, etc. R. R. Co. (1915), 169 Cal. 515, 147 Pac. 135.

57 Dierssen v. Nelson (1903), 138 Cal. 398, 71 Pac. 456.

5816 Cyc. 163.

59 Perich v. Maurer (1916), 22 Ca1. App. Dec. 42, 45, 155 Pac. 471. As said in other cases: "If they, or the places where they were cannot be located, it. would be important to ascertain the boundaries of the street as actually opened and used; and if such location has been generally acquiesced in by the public, by lot owners and the municipality, in the absence of more certain evidence, it will be conclusive." Orena v. City of Santa Barbara (1891), 91 Cal. 628, 28 Pac. 268. Likewise, "In the absence of better evidence, the court might have been war- 
How prolonged the acquiescence must be to operate without more is, of course, discretionary with the court or jury, as in all cases of "reasonable time," laches, and the like. In prescription this discretion was gradually crystallized to shorter and shorter periods, until even the requirement of being beyond living memory was shortened, by analogy, to the period of statutes of limitation. In the application of the doctrine of repose to acquiesced boundary limes it is still left to the court's discretion how long the acquiescence must continue to be per se productive of the determinative change of circumstances through natural loss of evidence and re-adjustment of living conditions. $^{60}$ There is a strong inclination to adopt the period of the statute of limitations here as in prescription. ${ }^{61}$

9. Where the acquiescence has not been prolonged, the change of circumstances requires actual proof. Making substantial improvements that would be jeopardized by moving the line is the usual proof. The statement of this in Helm v. Wilson has been often quoted and always cited with approval :62

"Besides, it appears that in I884 the defendant, with the knowledge and acquiescence of the plaintiff, erected valuable improvements upon the disputed 'strip.' It has been held that, even without any agreement more than is implied from their acts, if two persons trace their dividing line, and,

ranted in finding for appellants on the evidence as to the south boundary of Fourth street as it had been indicated on the ground by the line of fence and other improvements for twenty-five years." Hellman v. City of Los Angeles (1899), 125 Cal. 387, 58 Pac. 10.

${ }_{60}$ A generation, buildings and sidewalks, Crandall v. Mary (1913), 67 Ore. 18, 135 Pac. 188; 20 years, a fence and cultivation, Tanner v. Stratton (1914), 44 Utah, 253, 139 Pac. 940; 40 years, Farr. Development Co. v. Thomas (1912), 41 Utah, 1, 122 Pac. 906.

61 It is mentioned in pretty nearly every California case from Sneed v. Osborn (1864), 25 Cal. 619, to Wheatley v. San Pedro, etc. R. R. Co. (1915), 169 Cal. 505, 514, 147 Pac. 135.

In the analogous cases in the law of watercourses already mentioned, the same inclination to adopt this period is found. See cases cited supra, n. 30 .

$62 \mathrm{Helm}$ v. Wilson (1888), 76 Cal. 476, 486, 18 Pac. 604. In a recent case the party testified: "If I am compelled to move that part of my building which the plaintiff claims is on his part of the lot, I will have to cut off about eighteen inches of my house-it would practically ruin the house. It would take off the roof and part of the room that projects eighteen inches over the line claimed by plaintiff; it would certainly injure the building if that part of it were removed." The court said: "Under such circumstances what does equity require? We think there can be reasonably but one answer to the question. The moral and legal duty was cast upon appellant to make inquiry concerning these patent and obtrusive circumstances." Campbell v. Grennan (1910), 13 Cal. App. 484, 110 Pac. 156. 
both recognizing it as such, one goes forward with the knowledge and acquiescence of the other, and makes valuable improvements, so valuable as to work great injury to the party making them if the line be disturbed, the other will be estopped from afterward alleging such mistake as shall deprive the builder of his improvements, and especially if the party seeking to disturb the line knew, at the time the improveinents were made, all that he subsequently learned, or if he had the means of knowledge."

How soon the making of improvements operates rests in the court's discretion, as a question of fact in each case as to what is a reasonable time, even if the time be short of the statute of limitation period. ${ }^{63}$

What the improvements must be is a similar question of fact in each case. The example of widest application, interesting every owner in the state, is where a building has been erected along a particular line and acquiesced in. Lesser conditions are but a question of descending degree; such as a permanent costly stone wall (not a whole house); planting and cultivating the overlap; only a hedge or row of trees; a mere wooden fence; or least, just a row of stakes. These depend upon the circuinstances in the discretion of the court or jury, as a question of fact whether a substantial change of conditions has occurred that cannot be set aside without substantial injury. The hedge case inight raise a question whether it has been long cared for and specially perfected at much labor and expense that would be swept away, and so on. The planting and cultivation case might be affected by the size of the overlap. ${ }^{\text {st }}$ But the mere fence or row of stakes is obviously an inexpensive thing to move, and the denial of boundary location by a mere fence (in the absence of extensive lapse of time sufficient to cloud the origin of it by loss of evidence and the like) is no denial of the doctrine of acquiescence; nor do the authorities so deciding conflict with that doctrine. If there are no improvements or other changes of circumstances, such cases where the time is also not extensive necessarily fail, and are obviousily not opposed to the doctrine of acquiescence, as where the court said:

63 "In other cases it is said that the occupancy in pursuance of the agreement need not continue for the period of the statute of limitations. This is obviously so where other conditions creating an estoppel exist." Lewis v. Ogram (1906), 149 Cal. 508, 87 Pac. 60, 117 Am. St. Rep. 151,10 L. R. A. (N. S.) 610 .

os See Grant's Pass Co. v. Brown (1914), 168 Cal. 460, 143 Pac. 754. 
"Neither are there any equities by reason of defendants having put any improvements on the land," been made such as would make it equitable that the plaintiffs recover." $"$ 66

Io. The upholding of the line produced by buildings, upon this ground of the elemental necessity for keeping the graves of dead issues closed, the doctrine of repose, is strictly a law ground, not requiring resort to equity jurisdiction. And whether the case be of actual contract, or cases of estoppel by admissions, or cases by operation of law upon the doctrine of acquiescence, the built-up line becomes the line meant by the paper muniment of title. "It attaches itself to the title deeds" and becomes the conclusive interpretation of their meaning. ${ }^{87}$

II. And it necessarily follows, as the weight of all these authorities declares, that acquiescence, having its basis in lapse of time and changed conditions, operates as well where the paper position of the line is in ignorance or mistake, as where it is believed uncertain. Indeed, its widest application and the chief concern of the public policy which gave it rise, is where the paper line is neither known upon the ground nor believed by anyone to be uncertain, the parties being in the neutral everyday position that any variance in the line was not thought of-the neutral condition of unconscious ignorance. The encroachment is undiscovered until after it has been done, and "the necessary effect of a practical location is in general to establish a different line from the true line as originally existing;" ${ }^{88}$ it usually covers a discrepancy, not before thought of by either one. This neutral condition of unconscious ignorance or mistake is recognized in a number of direct decisions, and, we believe the weight of authority ${ }^{69}$ in these acquiescense cases." "70

65 Breen v. Donnelly (1887), $74 \mathrm{Cal} .301,15 \mathrm{Pac} .845$. So also in Allen v. Reed (1876), 51 Cal. 362, and McDonald v. Drew (1893), 97 Cal. 266, 32 Pac. 173, there was no building nor other improvement to be injured sufficient to constitute a substantial change of conditions.

e7 "The division line when thus established, attaches itself to the deeds of the respective parties, and simply defines, not adds to, the lands described in each deed, in accordance with the understanding of the parties, who are presumed to know best their lands;" Sneed v. Osborn (1864), 25 Cal. 619, 630. Accord, Young v. Blakeman (1908), 153 Cal. 477, 483, 95 Pac. 888; Price v. De Reyes (1911), 161 Cal. 484, 489, 119 Pac. 893 , citing other cases.

68 Western Union Oil Co. v. Newlove (1905), 145 Cal. 772, 774, 79 Pac. 542.

"S Sneed v. Osborn (1864), 25 Cal. 619, 626: "It will make no difference in the result that they acted in ignorance or under a mistake." 
The authorities seem also to establish that there is no force in the argument that the mistake attributes negligence in not having a survey. Beside assuming that a new survey is always a correct one, such argument overlooks that therein both parties are equally in the wrong (if it were a wrong). Thus, while a case in the District Court of Appeal introduces this as an argument against the encroacher, ${ }^{71}$ the failure to survey is as positively ruled in a frequently cited case in the Supreme Court as an argument against the party encroached upon. ${ }^{72}$ And cases in the Supreme Court have ruled that it is not material that "according to the calls of Mrs. Ashley's deed there could be no question of the

Compare McGee v. Stone (1858), 9 Cal. 600, 606, 2 Morr. Min. Rep. 238; Biggins v. Champlin (1881), 59 Cal. 113, 116: "It makes no difference that the parties, in making the location, acted under a mistake as to the true line." Helm v. Willson (1888), 76 Cal. 474, 486, 18 Pac. 604: "The other will be estopped from afterward alleging such mistake." Dundas y. Iankershim Dist. (1909), 155 Cal. 692, 102 Pac. 925. (Ground to be given for a school house was marked by surveyor. Owners on both sides thereupon planted adjoining rows of trees along the line. School house followed soon and completed up to that line. Mistake of forty feet later developed. Acquiesence held to fix the line). Loustalot v. McKeel (1910), 157 Cal. 634, 643, 108 Pac. 707: “.... such agreement is conclusive no matter whether they were mistaken or not in their belief that they were locating it along the true line. It is quite obvious that if the fact merely that the parties were mistaken. as to where the true line lay could invalidate their agreement, there never could be any stability attached to such an agreement unless the line agreed on was in truth the exact line." Price v. De Reyes (1911), 161 Cal. 484, 119 Pac. 893: "The position of the division line had not been marked." This was viewed per se enough. to cover any rule of uncertainty. Bree v. Wheeler (1906), 4 Cal. App. 109, 87 Pac. 255: "If the parties have carried the agreement into execution, and entered into possession in accordance with it, the courts will not disturb it, though both parties were mistaken as to the true location of the line." Compare Woodward v. Faris (1895), 109 Cal 17, 41 Pac. 781: " . . . if one of the coterminous owners takes possession and claims title to the extent of his possession, he holds adversely, although he was induced to locate his possession through a mistake as to the boundary." See also, Togni v. Slocum (1910), 12 Cal. App. 733, 736, 108 Pac. 723; Campbell v. Grennan (1910), 13 Cal. App. 481, 484, 110 Pac. 156 .

It is laid down likewise in other jurisdictions. See cases cited supra, n. 50. In one of them, Dieh1 v. Zanger (1878), 39 Mich. 601, Judge Cooley, concurring says: "If all the lines were now subject to correction on new surveys, the confusion of lines and titles that would follow would cause consternation in many communities. Indeed, the mischiefs that must follow would be simply incalculable, and the visitation, of the surveyor might well be set down as a great public calamity."

${ }_{70}$ The contrary rule applies in cases of agreements. Supra, par. 1. The acquiescence cases are independent of agreement.

71 Janke v. McMahon (1913), 21 Cal. App. 788, 133 Pac. 21. See also Honaker v. Heatly (1913), 21 Cal. App. 328, 131 Pac. 759.

${ }_{72} \mathrm{Helm}$ v. Wilson (1888), $76 \mathrm{Cal}$. 474, 484, 18 Pac. 604, quoted supra, par. 9. 
true location of the dividing line; that, as claimed by counsel for appellant, it was and is capable of ready ascertainment and location, ${ }^{73}$ and that whether the position of the paper he is "ascertainable" or not is an immaterial matter. ${ }^{74}$ Any argument upon means of finding out is equally applicable to both sides and neutralizes itself. ${ }^{25}$

One case assumes that presence of a "dispute" is of some necessity. ${ }^{76}$ The contrary is probably established by prior cases, and also a decision later. ${ }^{77}$ Dispute, instead of being an aid to the establishment of the line, is an impediment, since its office is to rebut acquiescence. ${ }^{78}$ Its service in establishing a line is given by being absent.

I2. This doctrine of acquiescence, effective not by contract but by operation of law (expressly excepted out of the Statute of Frauds), resting upon public policy, and so frequently applied in California, is denied in the recent case of Clapp v. Churchill. ${ }^{29}$ The ground taken in this case is that acquiescence could be considered only as evidence of an earlier agreement; hence only where a formal agreenent would have been valid; and a formal agreement fixing such line would not be valid unless both parties were shown to have believed the line uncertain.

Being tied to the position that the acquiescence cases rest upon an actual agreement, it is opposed by the numerous prior

73 Loustalot v. McKeel (1910), 157 Cal. 634, 641, 108 Pac. 707.

${ }^{74}$ Price v. De Reyes (1911), $161 \mathrm{Cal}$. 484, 119 Pac. 893.

75 If the mistake was suspected and the location made conditionally and only until the true line be found, there is no acquiescence. Supra, par. 8. But mistake has no other bearing where none was suspected and the location was unconditional.

${ }_{76}$ Clapp v. Churchill (1913), $164 \mathrm{Cal}$. 741, saying that there was "no dispute shown or uncertainty" and "This inference of a doubtful boundary will not prevail against the proved fact to the contrary-namely, that there was no question or doubt or dispute between the parties over the boundary." This revival of the element of "dispute" is, as a result, repeated in Honaker v. Heatly (1913), 21 Cal. App. 327, 131 Pac. 759.

78 Schwab v. Donovan (1913), 165 Cal. 360, 364, 132 Pac. 447: "It is not necessary that there should have been a dispute regarding the true line." Likewise Price v. De Reyes (1911), 161 Cal. 484, 486, 119 Pac. 893; Thaxter v. Inglís (1898), 121 Cal. 593, 54 Pac. 86; Helm v. Wilson (1888), 76 Cal. 474, 476, 18 Pac. 604 (leading case); Diehl v. Zanger (1878), 39 Mich. 601: "The question had not been mentioned between them and plaintiffs in error until a short time before this suit was commenced."

78 See par. 8, pagie 306 , supra.

79 Clapp v. Churchill (1913), 164 Cal. 741, 130 Pac. 1061. I California Law Review, 370 comments that Clapp v. Churchill "conflicts with many previous decisions of the court." 
cases based upon the ground that in the doctrine of repose the socalled agreement is a fiction only; that the implied agreement spoken of in the acquiescence cases is not a matter of contract more than the supposed grant in prescription. The presumed grant in prescription is well known not to be governed by contract, and if the test of an actual agreement stands as in Clapp v. Churchill, it would be proper to expect a ruling that the creation of prescriptive rights of way is withim the Statute of Frauds, and see their validity tested by the law of contracts.

These views in Clapp v. Churchill appear to be obiter only, since there was no extensive lapse of time (only one year over five years) and note is taken in the opinion that there were no substantial improvements to be jeopardized. Although accepted in two decisions in the District Courts of Appeal ${ }^{80}$ neither the other department of the Supreme Court nor the court in bank has yet fully done so. In the other department Schwab v. Donovan, ${ }^{81}$ decided since Clapp v. Churchill, rules "that all the parties acted in the belief that the fence was in fact the boundary." as this therefore holds, the parties may in ignorance or mistake believe in the truth of their own location, it is a later ruling showing that Department One does not concede the ruling of Department Two.

The weight of California authority seems still to hold that built-up boundaries outweigh paper boundaries by operation of law springing out of public policy, in which "agreement" is but a fiction of the law, or, better still, is not involved.

"And these fictions of law, though at first they may startle the student, he will find upon further consideration to be highly beneficial and useful; . . . . its proper operation being to prevent a mischief, or remedy an inconvenience, that might result from the general rule of law." 8 Recognized as a fiction the imphed boundary agreement from acquiescence, lapse of time and changed conditions is beneficent; confounded with the reality,

80 Honaker v. Heatly (1913), 21 Cal. App. 327, 329, 131 Pac. 759; Janke v. McMahon (1913), 21 Cal. App. 781, 788, 133 Pac. 21.

81 Schwab v. Donovan (1913), 165 Cal. 360, 364, 132 Pac. 447.

82 Compare this with the statement in Clapp v. Churchill (1913), $164 \mathrm{Cal} .741,130$ Pac. 1061: "There is no word of testimony that the defendants, or any one of them, believed or declared their northern boundary line to be uncertain."

833 Blackstone's Commentaries, 43. 
it lets in the evil itself which public policy invented the fiction to guard against. ${ }^{8 *}$

San Francisco, California.

Samuel C. Wiel.

84 The following California cases have been examined. They are apparently a complete list upon this subject. McGee v. Stone (1858), 9 Cal. 600, 2 Morr. Min. Rep. 238; Maye v. Yappen (1863), 23 Cal. 306, 10 Morr. Min. Rep. 101; Clarke v. Huber $(1864)$, 25 Cal. 594; Sneed v. Osborn (1864), 25 Cal. 619; Sneed v. Woodward (1866), 30 Cal. 430; Hastings v. Stark (1868), 36 Cal. 122; Irvine v. Adler (1872), 44 Cal. 559; Columbet v. Pacheco (1874), 48 Cal. 395; Moyle v. Connolly (1875), 50 Cal. 295; Allen v. Reed (1876), 51 Cal. 362; Biggins v. Champlin (1881), 59 Cal. 113; Cooper v. Vierra (1881), 59 Cal. 282; Shiels v. Haley (1882), 61 Cal. 157; Johnson v. Brown (1883), 63 Cal. 391; Truett v. Adams (1884), 66 Cal. 218, 5 Pac. 96; Quinn v. Windmiller (1885), 67 Cal. 461, 8 Pac. 14; Montgomery v. Locke (1887), 72 Cal. 75, 13 Pac. 401; White v. Spreckels (1888), 75 Cal. 610, 17 Pac. 715; Hughes v. Wheeler (1888), 76 Cal. 230 , 18 Pac. 386; Burris v. Fitch (1888), 76 Cal. 395, 18 Pac. 864; Helm v. Wilson (1888), 76 Cal. 476; 18 Pac. 604; Silvarer v. Hansen (1888), 77 Cal. 579, 20 Pac. 136; Helm v. Wilson (1891), 89. Cal. 593, 26 Pac. 1103; Cavanaugh v. Jackson (1891), 91 Cal. 580, 27 Pac. 931; Orena v. Santa Barbara (1891), 91 Cal. 621, 28 Pac. 268; McDonald v. Drew (1893), 97 Cal. 266, 32 Pac. 173; Woodward v. Faris (1895), 109 Cal. 12, 41 Pac. 781; Peters v. Gracia (1895), $110 \mathrm{Cal}$ 89, $42 \mathrm{Pac}$ 455; Eberhardt v. Coyne (1896), $114 \mathrm{Cal}$. 283, 46 Pac. 84; Thaxter v. Inglis (1898), 121 Cal. 593, 54 Pac. 86; Hellman v. City of Los Angeles (1889), 125 Cal. 383, 58 Pac. 10; Iucas v. Provines (1900), $130 \mathrm{Cal}$. 270, 62 Pac. 509; Nathan v. Dierssen (1901), 134 Cal. 282, 66 Pac. 485; Dierssen v. Nelson (1903), 138 Cal. 394, 71 Pac. 456; Western Union Oil Co. v. Newlove (1905), 145 Cal. 772, 79 Pac. 542; Lewis v. Ogram (1906), 149 Cal. 505, 87 Pac. 60, 117 Am. St. Rep. 151, 10 L. R. A. (N. S.) 610; Mann v. Mann (1907), 152 Cal. 23, 91 Pac. 994; Young v. Blakeman (1908), 153 Cal. 477, 95 Pac. 888; Dundas v. Lankershim School District (1909), 155 Cal. 692, 697, 102 Pac. 925; Loustalot v. McKeel (1910), 157 Cal. 634, 108 Pac. 707; Price v. De Reyes (1911), 161 Cal. 484, 119 Pac. 893; Fitzimons v. Atherton (1912), 162 Cal. 630, 124 Pac. 250; Clapp v. Churchill (1913), 164 Cal. 741, 130 Pac. 1061; Schwab v. Donovan (1913), 165 Cal. 360, 132 Pac. 447; Grant's Pass Land \& Water Co. v. Brown (1914), 168 Cal. 456, 143 Pac. 754; Wheatley v. San Pedro, Los Angeles \& Salt Lake R. R. Co. (1916), 169 Cal. 505, 147, Pac. 135; Bree v. Wheeler (1906), 4 Cal. App. 109, 113, 87 Pac. 255; Campbell v. Grennan (1910), 13 Cal. App. 481, 110 Pac. 156; Honaker v. Heatly (1913), 21 Cal. App. 327, 131 Pac. 759; Janke v. McMahon (1913), 21 Cal. App. 781, 133 Pac. 21; Barry v. Sutter (1914), 26 Cal. App. 240, 146 Pac. 527; Perich v. Maurer (1916), 22 Cal. App. Dec. 42, 155 Pac. 471; Smith v. Robarts (1885), 2 Cal. Unrep. Cas. 604, 9 Pac. 104. 